Kohl: a Journal for Body and Gender Research

Vol. 4, No. 2 (Winter 2018)

\title{
Divergent Identities in Iran and the Appropriation of Trans Bodies
}

\author{
Kate Hashemi
}

\begin{abstract}
:
While gender-based scholarship on the Islamic Republic of Iran (IRI) is largely centred on a woman's right to unveil, those adopting an LGBT+ framework tend to focus on human rights violations against homosexual males. This paper provides a more inclusive study in its assessment of the state's oxymoronic approach to trans persons in Iran and the use of gender affirming surgery to reposition its subjects in line with hegemonic notions of "healthy" sexualities. In this context, the Iranian woman, bound by a particular conception of Islamic femininity, and the Iranian man, embodied by the hyper-masculine martyr figure, are promoted as the only genderisms acceptable to the state. This binary of hetero-Muslim male/female excludes all other expressions of gender. Ignoring the country's historic array of masculinities and sexualities, the IRI criminalises gender "passing" in its limited notion of gender performativity. Furthermore, it utilises gender affirming surgery as a tool for repositioning divergent identities and sexualities within the state-sanctioned paradigm. While the state appropriates trans bodies to promote the ideal gendered subject, the framework of gender performativity is also adopted by regime critics to promote cis-gendered female agency: popular culture employs "cross-dressing" to contest the policing of heteronormative bodies and sexualities. Undoubtedly such methods are complicit in the continuation of discriminatory practices against trans persons in Iran.
\end{abstract}




\section{Introduction}

In Gender Trouble, Judith Butler contests the framework of a gender binary, as upheld in the popular imagination, for assuming a "causal relation among sex, gender, and desire." ${ }^{1}$ In that framework, gender is thence imagined within a binary of masculine/feminine, in which such characteristics are marked by sex assigned at birth. ${ }^{2}$ The 1979 revolution in Iran reinvigorated such discourses around gender identity. Notions of Islamic femininity and hyper-masculine martyrdom were secured within the dominant discourse as the "norm." Based on a dogmatic interpretation of Quranic genderisms, the Islamic Republic of Iran (IRI) provided an uncompromising binary of masculine/feminine. Within this paradigm of knowledge production, Iranian men are marked by the idealised hyper-masculine martyr figure signalled by Imam Hussein, whereas Iranian women are framed as daughters of Fatemeh, hailed within the bounds of Islamic femininity, as surmised by Ali Shariati. ${ }^{3}$ Within this discourse of binarized gender bound by Shi'i sensibility, however, is the apparent oxymoronic notion of the promotion of gender affirming surgeries. Following a fatwa issued by Ayatollah Khomeini in 1987, Iran performs more gender affirming surgeries than any other country, excluding Thailand. ${ }^{4}$ While this initially reads as a triumph for the trans community in Iran, the promotion of such surgeries acts to secure the hegemonic ideals of sex and gender as promoted by the state. Considering the illegality of non-heteronormative sexual practices in Iran, the state's notion of "healthy" sexualities is bound by the binary of the idealised, Muslim male/female. Although it has been widely reported that the Iranian authorities have legalised gender affirming surgeries while penalising those who deviate from the masculine/feminine framework, considerations of the ways in which trans bodies are exploited by critics of the regime have been largely ignored. While a particular conception of trans-ness is utilised by the state to uphold the hegemonic gender binary in Iran, state dissidents also appropriate notions of trans-ness to promote cis-gendered female agency. In order to demonstrate this effectively, this paper considers the binarization of gender in Iran, the existence of nonheteronormative gender identities and sexualities, and the fetishization of cross-dressing in popular culture.

\section{The Binarization of Gender in Iran}

The state's attitude towards non-heteronormative sexualities and genders in Iran is most famously depicted in Ahmadinejad's 2007 speech in which he denied the existence of homosexuality in Iran. This mind-set mimics the European "modernist" project at the turn of the twentieth-century, ${ }^{5}$ which presented gender and sexuality as binary constructs. Within this paradigm of knowledge production, reproductive justice is rendered impossible within the heteronormative framework of cis-gendered male to female

\footnotetext{
1 Judith Butler, Gender Trouble (New York: Routledge, 1999), 30.

2 Gender binarism may also be referred to as genderism.

${ }^{3}$ Ali Shariati, "Fatemeh Fatemeh Ast" [Fatemeh is Fatemeh] trans. Laleh Bakhtiar (Iran: The Shariati Foundation), http://gadir.free.fr/eng/books/FatimalsFatima.pdf [accessed 19 October 2018]

4 Euronews, "In Iran, you can't be gay but you can be transgender," 14 October 2015, https://www.youtube.com/watch?v=NsJGHVHF1ss [accessed 08 August 2018]

5 This refers to the age of Enlightenment in which European thinkers aimed to move away from traditionalism and barbarism and towards the "modern." Such reasoning was used as a means to justify colonial projects.
} 
relations. ${ }^{6}$ In importing European Enlightenment discourses on sex and sexuality, what Mahdavi terms Iran's "culturally complex"7 relationship with both homosexuality and gender fluidity is dismissed and replaced with the new hegemonic narrative of binarized gender. Najmabadi highlights the prevalence of non-binary masculine identities prior to the adoption of Enlightenment modes of gender and sexuality in Iran. While contemporary conceptions of fragmented machismo are equated to a feminisation of character, Qajar ${ }^{8}$ sensibilities were open to a diverse array of masculinities. ${ }^{9}$ Most notably, the beardless amrad (male adolescent) was positioned as an object of desire for (bearded) men in "pre-modern" Sufi homoerotic discourse. ${ }^{10}$ The amrad symbolised beauty in Qajar Iran and represented an official form of masculinity accepted within dominant discourse, prior to the turn of the century. Such divergent masculinities were eradicated with the temporal shift from "pre-modern" to "modern" and an internalisation of European anxieties on sexuality. ${ }^{11}$ This is not an attempt to romanticise the pre-modern era and its treatment of non-normative genders and sexualities; rather, it observes the historical erasures and discontinuities of the amrad culture in favour of a modernist project. As a result, homosexual/homosocial desires were unequivocally denied and later considered to be "imported" concepts. ${ }^{12}$

Under the Pahlavi dynasty, ${ }^{13}$ gender identities were bound by a particular conception of masculinity (as a singular phenomenon) that complemented emerging notions of statehood: the conception of modernity as a teleological phenomenon, and the "liberation" of the new Iranian woman from traditional Islamic codes. At that time, mam-e vatan (the motherland) was ruled by the Pahlavi father/king to promote a patriarchal vision of statehood. ${ }^{14}$ This binarization of gender branded any non-conforming characteristics as "other." Within this epoch, sexual education emphasised the "danger" of puberty. ${ }^{15}$ It is this same education that depicted the youth as vulnerable to "abnormal sexual inclinations." 16 "Sexual deviancy" was categorised as resulting from either a developmental failure (sickness due to psychological or biological causes) or degeneracy. ${ }^{17}$ While the notions of developmental failure may evoke a form of sympathy, the framing of same-sex desire as "degeneracy" implied a vilification of the act. Within this discursive framework, same-sex desire was treated indistinctly from practices of paedophilia,

\footnotetext{
${ }^{6}$ Abouzar Nasirzadeh, "The Role of Social Media in the Lives of Gay Iranians," in David M. Farid and Babak Rahimi, Social Media in Iran: Politics and Society after 2009 (New York: State University of New York Press, 2015), 60.

${ }^{7}$ Mahdavi, Pardis, "The personal is political and the political is personal: sexuality, politics, and social movements in modern Iran," in Peter Aggleton et al, Understanding Global Sexualities: New Frontiers (London and New York: Routledge, 2012), 44

8 The Qajar dynasty ruled Iran from 1794 to 1925.

9 Afsaneh Najmabadi, Women with Mustaches and Men without Beards: Gender and Sexual Anxieties in Iranian Modernity (Berkley, Los Angeles, and London: California Press, 2005), 3.

10 Katarzyna Korycki and Abouzar Nasirzadeh, "Desire recast: the production of gay identity in Iran," Journal of Gender Studies (2016) Vol. 25, No. 1, 55.

$11 \mathrm{lbid}, 39$.

$12 \mathrm{lbid}$.

13 The Pahlavi dynasty ruled from 1925 until the Iranian revolution in 1979.

${ }^{14}$ Minoo Moallem, Between Warrior Brother and Veiled Sister (California: University of California Press, 2005), 64.

${ }^{15}$ Afsaneh Najmabadi, Professing Selves: Transexuality and Same-Sex Desire in Contemporary Iran (Durham and London: Duke University Press, 2014), 52.

16 Mir Ahmad Hashimi-Fard, masa'il va ikhtilalati-e junsi dar zan va mard [Sexual Problems and Disorders in Women and Man] (Tehran: Chihr, 1969), 11.

17 Hasan Hasuri, raftar-e jinsi bar payah-e siksaufiziulauzhi [Sexual Behaviours on the Basis of Sexo-Physiology], (Tehran: Tahuri, 1968), 481.
} 
transvestism, and transsexuality. ${ }^{18}$ Such blurred lines led to the subsequent establishment of homosexuality as crime, and with transvestism and transsexuality blanketed under the same category, their resultant criminalisation. ${ }^{19}$ This categorisation marked a total break from the prior understanding of sexuality in Iran and the amrad culture of Sufi homoerotism. The dominant narrative on "sexual degeneracy" within this epoch considered same-sex desire a residual effect of the archaic social institution of gender segregation promoted in Islam. ${ }^{20}$ This argument established an exemplary model for the modernist project in their articulation of the necessity of women's participation in the public sphere, alongside the de-Islamification/de-Arabisation of society led by the Pahlavi regime. In this paradigm of thought production, the new Iranian woman was thrust into the public sphere through her (coerced) "freedom" from Islamic social codes. This narrative is best illustrated by the 1936 Unveiling Act in which women were forcibly unveiled to promote the country as both modernised and "westernised" in comparison to its "barbaric" Islamic neighbours.

\section{Hegemonic Notions of Gender in the IRI}

Revolutionary Iran ${ }^{21}$ provided alternative models for the Pahlavi masculinity, grounded in leftist revolutionary modes and the clergy. During the revolution, leftist movements, such as the mojahedin-e khalgh (worriers of the people) and fedaiyan-e khalgh (fighters of the people), presented their members as a homogenous masculine body. Female members rejected overt manifestations of femininity, dressing moderately and forgoing makeup. ${ }^{22}$ These women adopted masculine performative codes to protest the particular construction of femininity adopted by the Pahlavi state. The clergy, on the other hand, drew upon a particular conception of Islamic machismo to position itself against Pahlavi notions of masculinity. In this paradigm of thought, martyrdom provided an Islamic frame of reference for the re-masculinisation of the Iranian man. Through sacred martyrdom, Iranian men were called upon to emulate Imam Hussein, celebrating his javanmardi (chivalry), fotovat (manliness), and baradari (brotherhood). ${ }^{23}$ In commemorating the martyrdom of Hussein through ta'ziyeh (passion plays) and muharram processions during the revolution, ${ }^{24}$ protestors promoted a particular conception of Iranian masculinity grounded in Shi'i sacred remembrance: they utilised Shi'a commemoration through organised religious processions to highlight their dissent against the Pahlavi regime. During these demonstrations, raised fists were

\footnotetext{
${ }^{18}$ Afsaneh, Najmabadi, Professing Selves, 56.

The medicalised term transsexuality has been used here as distinct from the preferred umbrella term transgenderism to reflect the discourse of the time. The term transsexual has later been problematised due to the perceived emphasis on physical transition.

$19 \mathrm{lbid}$.

$20 \mathrm{lbid}, 60$.

21 Marked by the period leading up to the 1979 revolution.

22 Firoozeh Kashani-Sabet, Conceiving Citizens: Women and the Politics of Motherhood in Iran (Oxford and New York: Oxford University Press, 2011), 212.

${ }^{23}$ Mehri Honarbin-Holliday, "Emerging Forms of Masculinity in the Islamic Republic of Iran," in Annabelle Sreberny and Massoumeh Torfeh Ed. Cultural Revolution in Iran: Contemporary Popular Culture in the Islamic Republic (London and New York: I.B. Tauris \& Co. Ltd., 2013), 64.

${ }^{24}$ Muharram is the first month of the Islamic calendar. Processions during this month mark the Battle of Karbala, where Imam Hussein was martyred by the second Umayyad caliph in Shi'a meta-history.
} 
opened to reveal painted red palms, a symbolism of the Karbala paradigm. ${ }^{25}$ This trope became one of the central motifs within the revolution, evoking Islamic meta-history as the site of emulation for the Iranian man. Through the promotion of what Moghadam terms "body politics," 26 i.e. utilising the body as a site to visually consume ideology, these revolutionary forces established themselves as pitted against the "feminine"/weak Pahlavi regime. Revolutionary discourse painted the image of a Pahlavi Iran corrupted by "Western" imperial forces. It depicted the Pahlavi epoch as fetneh (seductress), calling it "the femme fatal of consumerism and Westernism." 27 Within this paradigm of knowledge production, men were portrayed as having lost their namus (honour) to the "painted doll" 28 of the Pahlavi regime for their acceptance of "Western" cultural hegemony. However, this period continued to perceive nonheteronormative expressions of maleness as "at once criminal, immoral, and theatrical." 29 Within this epoch, the "Islamist" oppositional movement presented the eruption of more visible displays of nonheteronormative maleness as a resultant dynamic of gharbzadegi ("West-struckness"). Al-e Ahmad portrays such divergent masculinities as a form of cultural corruption in his assertion that:

[the] West-stricken man is a gigolo. He is effeminate. He is always primping, always making sure of his appearance. ${ }^{30}$

For Al-e Ahmad, to be vulnerable to imperialist culture is to be effeminate. Thus, it follows that the nation's gender identities and expressions must be controlled to deflect processes of colonisation and emasculation, protecting the ghairat (male-honour) of the state. ${ }^{31}$ Such rhetoric was bound by class: the ruling classes were condemned by revolutionary ideologues for their apparent emasculation. The dissemination of rumours about Pahlavi court culture as homoerotic accused the ruling class of further moral corruption. ${ }^{32}$ The portrayal of the Pahlavi regime as fetneh was thus further fermented with this suggestion of an aspect of "sexual deviancy." Within this discursive paradigm, non-heteronormative maleness was linked to the corruption of power of the mustakbirin (arrogant). Such categorisation provided a binary model for the mustazafin (disinherited), who emerged as uncorrupted hyper-masculine figures, untainted by the homoerotism of the ruling class. While the dominant discourse during the Pahlavi epoch equated homosocial and homosexual behaviour to Islamic "backwardness," revolutionary ideologues reframed notions of masculinity to present the Shah's regime as both effeminate and corrupt. This discourse paved the way for the emergence of the new Iranian man, at once hyper-masculine and pious. Moreover, with the implementation of body politics in the legislative framework of the IRI after the revolution's success, male non-heteronormativity was further policed by the state.

\footnotetext{
25 Peter Chelkowski and Hamid Dabashi, Staging a Revolution: The Art of Persuasion in the Islamic Republic of Iran (London: Booth-Cibborn Editors, 2000), 74.

${ }^{26}$ Valentine M. Moghadam, "Revolution, Religion, and Gender Politics: Iran and Afghanistan Compared," Journal of Women's History (Winter 1999), 174.

${ }^{27}$ Shahin Gerami, "Mullahs, Martyrs, and Men: Conceptualizing Masculinity in the Islamic Republic of Iran," Men and Masculinities (January 2003), Vol. 5, No. 3, 265.

28 The Pahlavi regime was designated as a "painted doll" by Al-e Ahmad in Jalal Al-e Ahmad Gharbzadegi [Weststruckness] (Mazda Publishers, 2012).

${ }^{29}$ Afsaneh, Najmabadi, Professing Selves, 136.

30 Jalal Al-e Ahmad, 90.

31 Nima Naghibi, Rethinking Global Sisterhood: Western Feminism and Iran (Minneapolis and London: University of Minnesota Press, 2007), 57.

32 Afsaneh, Najmabadi, Professing Selves, 136.
} 


\section{Non-Heteronormative Identities and Sexualities}

The rigid marking of accepted gender performativity under the IRI deemed gender "passing"33 a criminal offence. Thenceforth, both trans and non-binary individuals faced the punitive measures of the newly imposed gender coding of the state. ${ }^{34}$ The criminality of gender "passing" is somewhat confusing, given Khomeini's 1987 fatwa legalising gender affirming surgery. ${ }^{35}$ Undoubtedly, Iran holds a unique position in the region due to its official acceptance, and even promotion of, gender affirming surgery. It is estimated that of Iran's 80 million citizens, under 50,000 identify as transgender. ${ }^{36}$ However, providing what Najmabadi terms a "categorical bifurcation of gay and transsexual," 37 Khomeini's fatwa was limited in its reliance on binary modes of gender identification. In fact, gender affirming surgery is governed by Islamic, rather than substantive law. This has resulted in a particular conception of transsexuality promoted by the state that actually constitutes a misrecognition of the rights of trans persons in Iran, ${ }^{38}$ who are viewed as having an illness that can be medically fixed through surgical means. There is no recognition of gender as a social construct or acceptance of non-binary individuals. Gender affirming surgery in official state discourse is understood as a repositioning of the self as either heterosexual male or heterosexual female. As the emphasis is placed on a surgical "cure," trans rights post-surgery are not a primary (or even secondary) concern of the authorities. Moreover, people whose gender identification is fluid and subject to change are excluded from such legal modes of protection. Gender-fluid persons who refuse gender affirming surgery may be at risk due to the illegality of "cross-dressing." 39 The state fervently refuses to acknowledge the preferred gender identity of trans persons who either do not want to, or cannot afford to, ${ }^{40}$ pursue gender affirming surgery. Therefore, individuals identifying as trans in Iran are only accepted by the state if their reproductive organs match their gender identities, as per the binarized understanding of both gender and sex. Additionally, the only people allowed such surgeries are those who have been officially diagnosed with gender identity "disorder."41 This rigid interpretation of gender identification is highly dysfunctional, as such policies directly impact a transgender person's right to health in Iran. Not only are gender affirming surgeries often carried out without a full consideration of alternative therapeutic

33 While "passing" in English can refer to when a transgender person is generally perceived as cisgender, I am using the term "passing" here to refer to moving from one gender to another.

34 Ibid, 161.

35 Mehrdad Alipour, "Islamic shari'a law, neotraditionalist Muslim scholars and transgender sex-reassignment surgery: A case study of Ayatollah Khomeini's and Sheikh al-Tantawi's fatwas," International Journal of Transgenderism (2016), Vol. 18, No. 1, 96.

36 The New Arab, "Transgender people in Iran face discrimination despite fatwa," 21 May 2018, https://www.alaraby.co.uk/english/society/2018/5/21/transgender-people-in-iran-face-discrimination-despite-fatwa [accessed 02 August 2018]

${ }^{37}$ Afsaneh, Najmabadi, Professing Selves, 161.

38 Zara Saeidzadeh, "Transsexuality in Contemporary Iran: Legal and Social Misrecognition," Feminist Legal Studies, 27 October 2016, https://link.springer.com/content/pdf/10.1007\%2Fs10691-016-9332-x.pdf [accessed 10 August 2018]

39 The term "cross-dressing" is used tentatively here to describe the act of wearing clothing designed for the opposite sex. While it is understood that the act of "cross-dressing" is different to trans persons adopting the dress of their preferred gender, the term is used here to signal the discourse of the state.

40 While gender assignment surgeries are subsidised by the state, the sum left to pay by the recipient is still in the thousands.

41 Ibid 
approaches, but many transgender persons in Iran are also subjected to negligent and sub-standard surgeries. ${ }^{42}$

In addition to the limited scope under which gender affirming surgeries are implemented, the legality of such practices does not protect trans persons from social stigma and abuse. Although the government has provided some support to trans people in allowing, and indeed subsidising such surgeries, the state has played no role in reforming attitudes towards trans persons or providing any form of safe space or secondary care. Because of this, trans people in Iran continue to face harassment, discrimination in the workplace, and abuse. ${ }^{43}$ Ashram, a transgender woman who has chosen not to undergo gender affirmation surgery, highlights the double hardship faced by those who refuse to conform to conventional gender roles. Her attempts to live openly as a transgender woman in Iran have been met with backlash from her family, wider society, and the government. She explains:

Both my family and the government have turned me into an isolated kind of person. I can't go out and do stuff, or just register at a gym or a club or something, I can't even go to an amusement park. They make you disappointed with life. That's what they want, actually. ${ }^{44}$

Certainly, Ashram's story is not unique. Due to the continuation of social stigma here, trans persons are often faced with isolation, joblessness, homelessness, and may resort to sex work to survive. ${ }^{45}$

Furthermore, due to both the stigmatisation and outright repression of homosexuality in Iran, those identifying as homosexual have often resorted to gender affirming surgery in order to live within the confines of the state. If gender affirming surgery is promoted by the regime as a means to re-position an "undesirable" (and illegal) profile within a recognisable binary of heteronormativity, the official discourse in Iran positions homosexuality as an illness. On commenting on the issue of homosexuality, Mohammad Javad Ardeshir Larijani, the head of Iran's Human Rights Commission, stated:

This is an illness which has to be cured with psychological, biological, and even physical care. We must confront the matter as a clinical issue. ${ }^{46}$

These comments mimic the regime's official approach towards homosexuality and the use of healthcare to "cure" non-heteronormative sexualities and gender identities. The IRI thus utilises such methods to surgically correct moshkeldaar ("gender-troubled") individuals so that they fit into the hegemonic notion

\footnotetext{
42 Justice for Iran, Diagnosing Identities, Wounding Bodies: Medical Abuses and Other Human Rights Violations Against Lesbian, Gay, and Transgender People in Iran (Germany: Justice for Iran, 2014), 143.

43 The New Arab, "Transgender people in Iran face discrimination despite fatwa," 21 May 2018, https://www.alaraby.co.uk/english/society/2018/5/21/transgender-people-in-iran-face-discrimination-despite-fatwa [accessed 25 October 2018]

44 Radio Free Europe/Radio Liberty, "Transgender in Tehran: Ashram's Story," 21 December 2017, https://www.rferl.org/a/iran-transgender/28931543.html [accessed 25 October 2018]

45 Youtube, Euronews, "Iran's transgender community: Legally recognised yet socially ostracised," 12 January 2018, https://www.youtube.com/watch?v=SM2IYVysd1Y [accessed 15 October 2018]

46 Manuchehr Lenz Iran, "Javad Larijani responds to UN rapporteur Ahmad Shahid: Homosexuality is a bad illness!," 08 March 2013, https://www.youtube.com/watch?v=8Wh0sniDCX0 [accessed 29 August 2018]
} 
of gender and sexuality in Iran. ${ }^{47}$ The government gives grants to individuals as an incentive to "fix" such deviances. These methods perpetuate hegemonic and patriarchal understandings of "healthy" sexualities within the heteronormative binary of straight male/female, while facilitating the abuse of nonheteronormative individuals in healthcare settings. Trans bodies are therefore appropriated by the state in an attempt to "fix" non-heteronormative sexual identities. According to Arsham Parsi, an LGBT+ human rights activist, almost half of the sex change operations are performed on persons who self-identify as homosexual, as an attempt by the state to "cure" their same-sex desire. 48 By placing the emphasis on a clinical "cure" for "the moshkeldaar," the state evades all responsibilities of individual care. Therefore, although the legalisation of gender affirming surgery is a positive step for trans persons in Iran in providing an accessible means for medical transition, its implementation has been highly limited due to the state's relentless emphasis on the gender binary.

\section{Notions of "Cross-Dressing" in Popular Culture}

In addition to the appropriation of trans bodies by the state to enforce hegemonic conceptions of gender in Iran, critics of the regime have also appropriated notions of transness to further their own agenda. Gender performance in the IRI is regulated by the morality police, gasht-e ershad (guidance patrol). While there is no explicit law in Iran for "cross-dressing," people who wish to dress in a way that is deemed to be associated to the opposite sex face persecution based on laws relating to hejab, and conduct deemed haram (religiously forbidden). ${ }^{49}$ Iranians are monitored for gender-inappropriate appearances and behaviours, such as long/"Western" hairstyles for men, "unladylike" behaviour for women, and decadent or obscene dress..$^{50}$ Citizens are expected to conform to heteronormative identities and behaviours within the confines of Muslim sensibilities. In such a restrictive climate, cultural items such as makeup and dress become signifiers of resistance. Those with bad-hejab (improper religious dress) provide a semiotic reference to what de Certeau deems resistance via everyday practices. ${ }^{51}$ The overt use of makeup and amount of hair showing underneath a roopoosh (headscarf) determines a physical representation of disenchantment against the body politics of the regime for Iranian women. In a society with gross limitations on freedom of expression, resistance is made visible by markers of appearance.

Butler furthers her conception of gender performativity in her work on subversive performative practices. She distinguishes parody as a form of repetition that may strategically act to denaturalise socially constructed gender codes. ${ }^{52}$ "Cross-dressing," then, becomes a tactical site of resistance against hegemonic conceptions of gender performativity. In Gender Trouble, Butler deems drag as indirectly

\footnotetext{
${ }^{47}$ Raha Bahreini, "From Perversion to Pathology: Discourses and Practices of Gender Policing in the Islamic Republic of Iran," Muslim World Journal of Human Rights, 2008, Vol. 5, No. 1, 2.

48 Simon Forbes, "The Reconstruction of Homosexuality and its consequences in contemporary Iran," The SOAS Journal of Postgraduate Research, Vol. 10, 32.

49 Justice for Iran, $52-53$.

50 Raha Bahreini, 6.

51 Naghibi, 67.

52 Julia Allerstorfer, 'Performing Visual Strategies: Representational Concepts of Female Iranian Identity in Contemporary Photography and Video Art', in Staci Gem Scheiwiller Ed. Performing the Iranian State: Visual Culture and Representations of Iranian Identity (London and New York: Anthem Press 2013), 180
} 
revealing "the imitative structure of gender itself - as well as its contingency." ${ }_{33}$ The enacted gender performativity displayed within different modes of "cross-dressing" emphasises the active construction of gender tropes through such gender slippage via mimicry. The ability to mimic gender thus deconstructs its perceived authenticity. ${ }^{54}$ Gender "passing" and "cross-dressing" are iconographic themes of New Iranian Cinema. These themes are utilised to question the validity of enforced gender codes. Kheshti presents this "transgender move" as a tactical site for political and agential action. ${ }^{55}$ Within this particular framework of resistance, "cross-dressing" is negotiated as a means to portray "unveiled" (female) agency. ${ }^{56}$ Certainly, in renowned dissident Panahi's 2006 film Offside, 57 "cross-dressing" is utilised as a form of political action and resistance, providing female characters with a means to trespass into spaces designated as "male-only" by the authorities. The film's portrayal of a number of girls who masquerade as men in order to enter Azadi stadium to watch a World Cup qualifying match questions not only the illegality of women entering football stadiums, but also takes to task the strict enforcement of Islamic dress in wider society. In adopting "male" dress, the women in Offside attempt to gain a taste of the privileges afforded to men in the IRI. New Iranian Cinema has thus embraced "cross-dressing" as a discursive site in which to resist state-imposed limitations on citizens' mobility, contesting the gendered spaces of the IRI. The heteronormativity of "cross-dressing" in new Iranian Cinema is highlighted in the film A Girl Named Tondar. 58 The story follows the life of an Iranian girl who was raised as a boy. In the film, the protagonist relinquishes the temporary mobility gained from her "cross-dressing" for the fairytale ending of heterosexual love. ${ }^{59}$ Rather than utilising "cross-dressing" to explore nonheteronormative identities in Iran, New Iranian Cinema therefore employs such themes to contest the policing of heteronormative bodies and cis-gendered agency. What is of note here is that gender "passing" as a theme in and of itself is left unexplored and the binarization of gender promoted by the state wholly uncontested. The sole issue taken to task by employing "cross-dressing" as a theme is the right of women to unveil and enter spaces reserved for men. "Cross-dressing" is merely utilised as a tool for the promotion of women's rights and heterosexual desire. The theme of "cross-dressing" in popular culture is thus reappropriated from the trans framework as a political tool for cis bodies.

Arguably, while state critics are not taking as large a role as the government in the abuse of nonheteronormative persons in Iran, their adoption of the trans framework without adequate reference perpetuates the context in which the rights of trans persons can be ignored. This is particularly the case when considering that only women appear in scenes with "cross-dressing" elements. While it is more tolerated for women to "cross-dress" in dominant discourse, due to both the sexualisation of women in "men's clothes" and the lack of threat to hegemonic conceptions of masculinity, New Iranian Cinema's over reliance on female "cross-dressing" acts to support the notion of male "cross-dressing" as taboo. In upholding the taboo, the Iranian authorities are able to continue practices of forcing men to dress as

\footnotetext{
53 Judith Butler, Precarious Life: The Powers of Mourning and Violence (London and New York: Verso Books, 2006), 187.

54 Julia Allerstorfer, 180

55 Roshanak Kheshti, 'Cross-Dressing and Gender (Tres)Passing: The Transgender Move as a Site of Agential

Potential in the New Iranian Cinema', Hypatia (Summer 2009), Vol. 42, No.3, 162.

56 Kheshti, 161.

57 Offside, 2006, Jafar Panahi Film Productions, Iran.

${ }^{58}$ A Girl Named Tondor, 2000, Hamidreza Ashtianipour, ClCinema, Iran.

${ }^{59}$ Reza Sadr Reza, Iranian Cinema: A Political History (London and New York: IB Tauris, 2006), 241.
} 
women as a form of punishment via public humiliation. 60 In disseminating images of detained men dressed in "women's clothes," Iranian authorities attempt to embarrass the targeted men through an exposed femininity, equating it to narratives of sexual deviancy. This method facilitates a means for the regime to revoke a man's namus by questioning his masculinity. ${ }^{61}$ Undoubtedly, it is through such practices that the binarization of gender is upheld. In order to break this binary, it is important to adopt an intersectional and holistic approach to justice, instead of focusing solely on cis-gendered women's rights.

\section{Conclusion}

Non-heteronormative gender identities and sexualities in Iran are heavily discriminated against despite the legality of gender affirming surgery. The IRI's reinforcement of the gender binary has given rise to a rigid system of demonization for those who do not conform to heteronormativity. The Islamic Republic's legalisation of gender affirming surgeries has certainly provided some form of progress for trans persons in Iran. However, this is limited to those who both want to, and can afford to, undergo such treatment. These policies ignore Iran's "culturally complex" relationship with non-binary forms of gender expression. In equating non-heteronormativity with both Pahlavi and "Western" performance, the authorities are able to strategically forget cultural practices such as the sexualisation of the amrad male, while presenting heteronormativity as an indigenous concept. In pitting non-binary culture as "other," the Iranian government gains a form of ideological legitimacy for its continued oppression of non-heteronormative identifying persons. This takes place through the criminalization of homosexual practices and imposition of gender codes. The state facilitates the exploitation of trans bodies and frameworks to promote hegemonic genderisms in its utilisation of gender affirming surgeries as a means to "fix" nonheteronormative identities and sexualities. In observing the role played by New Iranian Cinema in facilitating the continuation of such practices, via the fetishization of "cross-dressing" and trans performative frameworks, it becomes evident that popular culture must employ such frameworks more progressively. Rather than treating "cross-dressing" as a tool for cis-female agency, New Iranian Cinema should look into intersectional and holistic frameworks in its dissent against gendered, state-imposed limitations on civic freedoms.

60 Tavaana, "'We are all Majid': International Solidarity for Iran," https://tavaana.org/en/content/we-are-all-majidinternational-solidarity-iran [accessed 24 October 2018]

Y Net News, "Iran uses cross-dressing as punishment," 22 April 2013,

https://www.ynetnews.com/articles/0,7340,L-4370864,00.html [accessed 24 October 2018]

61 Fatemeh Sadeghi, "The Green Movement: A Struggle against Islamic Patriarchy," in Negin Nabavi Ed. Iran:

From Theocracy to the Green Movement (New York: Palgrave MacMillian, 2012), 131. 


\section{References}

Articles

Aggleton, Peter, Paul Boyce, Henrietta L. Moore, and Richard Parker Ed., Understanding Global Sexualities: New Frontiers (London and New York: Routledge, 2012).

Alipour, Mehrdad, "Islamic shari'a law, neotraditionalist Muslim scholars and transgender sexreassignment surgery: A case study of Ayatollah Khomeini's and Sheikh al-Tantawi's fatwas," International Journal of Transgenderism (2016), Vol. 18, No. 1.

Bahreini, Raba, "From Perversion to Pathology: Discourses and Practices of Gender Policing in the Islamic Republic of Iran," Muslim World Journal of Human Rights, 2008, Vol. 5, No. 1, 2.

Butler, Judith, Gender Trouble (New York: Routledge, 1999).

Butler, Judith, Precarious Life: The Powers of Mourning and Violence (London and New York: Verso Books, 2006).

Chelkowski, Peter and Hamid Dabashi, Staging a Revolution: The Art of Persuasion in the Islamic Republic of Iran (London: Booth-Cibborn Editors, 2000).

Farid, David M. and Babak Rahimi, Social Media in Iran: Politics and Society after 2009 (New York: State University of New York Press, 2015).

Forbes, Simon, "The Reconstruction of Homosexuality and its consequences in contemporary Iran," The SOAS Journal of Postgraduate Research, Vol. 10, 32.

Gem Scheiwiller Staci Ed. Performing the Iranian State: Visual Culture and Representations of Iranian Identity (London and New York: Anthem Press 2013).

Gerami, Shahin, "Mullahs, Martyrs, and Men: Conceptualizing Masculinity in the Islamic Republic of Iran," Men and Masculinities (January 2003), Vol. 5, No. 3.

Hashemi-Fard, Mir Ahmad, masa'il va ikhtilalati-e junsi dar zan va mard [Sexual Problems and Disorders in Women and Man] (Tehran: Chihr, 1969).

Hasuri, Hasan, raftar-e jinsi bar payah-e siksaufiziulauzhi [Sexual Behaviours on the Basis of SexoPhysiology], (Tehran: Tahuri, 1968).

Justice for Iran, Diagnosing Identities, Wounding Bodies: Medical Abuses and Other Human Rights Violations Against Lesbian, Gay, and Transgender People in Iran (Germany: Justice for Iran, 2014).

Kashani-Sabet, Firoozeh, Conceiving Citizens: Women and the Politics of Motherhood in Iran (Oxford and New York: Oxford University Press, 2011).

Kheshti, Roshanak, "Cross-Dressing and Gender (Tres)Passing: The Transgender Move as a Site of Agential Potential in the New Iranian Cinema," Hypatia (Summer 2009), Vol. 42, No. 3.

Korycki, Katarzyna and Abouzar Nasirzadeh, "Desire recast: the production of gay identity in Iran," Journal of Gender Studies (2016), Vol. 25, No. 1.

Moallem, Minoo, Between Warrior Brother and Veiled Sister (California: University of California Press, 2005).

Moghadam, Valentine M., "Revolution, Religion, and Gender Politics: Iran and Afghanistan Compared," Journal of Women's History (Winter 1999).

Nabavi, Negin, Ed. Iran: From Theocracy to the Green Movement (New York: Palgrave MacMillian, 2012). Naghibi, Nima, Rethinking Global Sisterhood: Western Feminism and Iran (Minneapolis and London: University of Minnesota Press, 2007). 
Najmabadi, Afsaneh, Women with Mustaches and Men without Beards: Gender and Sexual Anxieties in Iranian Modernity (Berkley, Los Angeles, and London: California Press, 2005).

Najmabadi, Afsaneh, Professing Selves: Transexuality and Same-Sex Desire in Contemporary Iran (Durham and London: Duke University Press, 2014).

Sadr Reza, Reza, Iranian Cinema: A Political History (London and New York: IB Tauris, 2006).

Sreberny, Anabelle and Massoumeh Torfeh Ed., Cultural Revolution in Iran: Contemporary Popular Culture in the Islamic Republic (London and New York: I.B. Tauris \& Co. Ltd., 2013).

Websites

Euronews, "In Iran, you can't be gay but you can be transgender," 14 October 2015, https://www.youtube.com/watch?v=NsJGHVHF1ss [accessed 08 August 2018]

Manuchehr Lenz Iran, "Javad Larijani responds to UN rapporteur Ahmad Shahid: Homosexality is a bad illness!," 08 March 2013, https://www.youtube.com/watch?v=8Wh0snjDCX0 [accessed 29 August 2018]

Radio Free Europe/Radio Liberty, "Transgender in Tehran: Ashram's Story," 21 December 2017, https://www.rferl.org/a/iran-transgender/28931543.html [accessed 25 October 2018]

Saeidzadeh, Zara, "Transsexuality in Contemporary Iran: Legal and Social Misrecognition," Feminist Legal Studies, 27 October 2016, https://link.springer.com/content/pdf/10.1007\%2Fs10691-0169332-x.pdf [accessed 10 August 2018]

Shariati, Ali, "Fatemeh Fatemeh Ast" [Fatemeh is Fatemeh] trans. Laleh Bakhtiar (Iran: The Shariati Foundation), http://gadir.free.fr/eng/books/FatimalsFatima.pdf [accessed 19 October 2018]

Tavaana, "We are all Majid': International Solidarity for Iran," https://tavaana.org/en/content/we-are-allmajid-international-solidarity-iran [accessed 24 October 2018]

The New Arab, "Transgender people in Iran face discrimination despite fatwa," 21 May 2018, https://www.alaraby.co.uk/english/society/2018/5/21/transgender-people-in-iran-facediscrimination-despite-fatwa [accessed 02 August 2018]

$Y$ Net News, "Iran uses cross-dressing as punishment," 22 April 2013, https://www.ynetnews.com/articles/0,7340,L-4370864,00.html [accessed 24 October 2018]

YouTube, Euronews, "Iran's transgender community: Legally recognised yet socially ostracised," 12 January 2018, https://www.youtube.com/watch?v=SM2/YVysd1YY [accessed 15 October 2018]

Films

A Girl Named Tondor, 2000, Hamidreza Ashtianipour, ClCinema, Iran.

Offside, 2006, Jafar Panahi Film Productions, Iran. 